\title{
Innovation Processes in Small and Medium Enterprises Associated in Networks from the Supermarket Sector
}

\author{
Rosália Rodrigues Alves', Mariane Figueira², Cleber Carvalho de Castro ${ }^{3}$, Joel Yutaka Sugano ${ }^{4}$, \\ Ari de Souza Soares ${ }^{5}$
}

\begin{abstract}
This study evaluates the types of innovation that Small and Medium Enterprises (SMEs) associated in networks develop in order to enjoy competitive benefits offered by those networks. The present study developed qualitative multiple case study of two networks from the supermarket sector, one vertical network and one horizontal network, which operate in southern region of Minas Gerais, Brazil. The results allowed concluding that organizational changes companies had to implement in order to enjoy the benefits they had considered competitive, enabled with their participation in the networks, can be considered organizational innovations. Data analysis revealed that innovations implemented by companies, resulted in other types of innovation, such as other organizational service innovations. It should also be mentioned that the innovation processes showed differences in their form in the two networks studied. In the vertical network, innovation occurred from the top-down. In the horizontal network, innovation occurred from the bottom-up.
\end{abstract}

Keywords: Brazil; amazonia; public investments; biotechnology; patents; science, technology and innovation (st\&i); research and development ( $\&$ d); innovation; amazonian bioproducts; sustainability.

Federal University of Lavras. Brazil.

E-mail: 'rosaliaadm@gmail.com, ${ }^{2}$ mari.figueira@gmail.com, ${ }^{3}$ clebercastrouai@gmail.com, ${ }^{4}$ joel.sugano@gmail.com, ${ }^{5}$ arisoares@gmail.com 


\section{Introduccion}

Internationalization of markets and changes in the competitive environment of firms are some of the characteristics of the new paradigm of "knowledge-based economy", in which learning plays an important role and requires flexibility and action from companies willing to sustain or improve market positions.

In such a context, two elements seem to be crucial to the sustainability of firms' competitive advantage: more flexible organizational structures, allowing access to information and capabilities the company lacks internally, and continuous innovation, which enables the company to create and deliver greater value to customers.

Within this scenario, Small and Medium Enterprises (SMEs) are pressured by larger companies which have better resource conditions to establish competitive strategies.

On the other hand, network associations, seeking collective strategies to face fierce competition, have been studied as an alternative for the competitiveness of SMEs. Within networks, these companies share information, enhance their ability to learn, and get also other benefits such as joint purchasing, marketing improvements, cost reductions and greater bargaining power.

Furthermore, with increasing access to the flow of information and knowledge, enabled by network associations, SMEs are empowered to innovate in services, processes and organizational structures to better meet the needs of their customers and, therefore, be able compete with large companies.

Companies in the service sector, which are very significant for the Brazilian economy, also seek to be innovative in order to be competitive, conquer new market shares, and sustain extant markets. In this context, the present study has as its main objective to evaluate which types of innovation SMEs associated in networks develop in order to enjoy the competitive benefits offered by those networks.

This study had as its focus the analysis of two networks of SMEs in the supermarket sector - one vertical network, coordinated by a wholesaler and one horizontal network, coordinated collectively by the participating companies. These two networks were chosen due to the relevance of their role in the southern region of Minas Gerais, Brazil.

Besides this introduction, this study is divided into five parts. In the next section, we have developed a theoretical overview of the formation of networks by SMEs and some of the competitive benefits of those networks. Subsequently innovation is discussed, focusing on service innovation and organizational innovation, necessary for understanding the concept of innovation in the present study. Section four outlined the methods and procedures used to conduct this study. The fifth section presented our main results, and the sixth exposed our discussion and conclusions.

Small and Medium Companies' Networks

The term "network" has become a common element used to describe a variety of phenomena ranging from social practices to economic activities. In the context of organizational studies, the term has been used for both, to refer to organizational forms, as well as to present a path in the pursuit for economic advantage (Nohria, 1992).

Borgatti and Foster (2003) define the network as a set of actors connected by a set of ties. According to the scholars, a set of ties of a given type, such as friendship, constitutes a binary social relation, and each relation defines a different network - the friendship network is different from the advice network - and different kinds of ties are typically assumed to function differently, developing different functions in each particular type of network.

Ahuja (2000), on the other hand, argues that networks are used by associated companies as a means for collecting and processing information.

Several scholars (Casarotto Filho and Pires, 1998; Baum and Ingram, 2000; Castells, 2007) characterize the networks split into two broad groups, namely, horizontal and vertical networks.

Horizontal networks emerge and operate based upon joint decision making - one head one vote. Baum and Ingram (2000) draw attention to the fact that horizontal networks are formed by similar organizations, which for that fact present great potential to competing with each other.

Drawing on evidence compiled from literature, Balestrin and Vargas (2004) have pointed some features of SMEs' horizontal networks:

a) those networks are formed by a group of small and medium companies;

b) SMEs are located geographically close;

c) SMEs operate at an specific market segment;

d) the relationship between SMEs are horizontal and cooperative, mutual trust prevails;

e) networks are formed by an indefinite period of time;

f) coordination of the networks is carried out from minimum contractual tools that guarantee basic governance rules. 
Balestrin and Vargas (2004) argue that the network horizontality is reached due to the participatory manner of decision-making processes, in which power symmetry between participants is present.

The vertical network on the other hand, has in its organizational structure small companies as suppliers or sub-suppliers of a parent-company. This type of network can also be called top-down network. In this model the supplier is dependent on the strategies of the parent company and has no influence on the development of the network (Casarotto Filho and Pires, 1998).

Olivares (2003, p.40), understands the vertical network as "a kind of network composed by complementary organizations operating in a value chain, offering a part of the service, operation or final product." According to the author, the various companies' actions are coordinated by a central organization, which relies on the core capabilities of each member to provide cost reductions and added value for the organizations involved in the process.

Regardless of its type, the formation of a network by means of interrelationships between companies is an effective way to sustain competitive positions (Balestrin and Vargas, 2004). Amato Neto (2000) listed some competitive gains enabled with network participation:

a) Combining core competences and using know-how from other companies;

b) Sharing resources;

c) Dividing the risk of technological research and development, sharing acquired knowledge and development;

d) Sharing costs of exploring new opportunities;

e) Offering a line of products of superior quality;

f) Exercising greater pressure on the market, increasing competitive strength for the benefit of the client, and

g) Strengthening purchasing power.

The competitive gains mentioned by Amato Neto (2000) can be seen as actions that promote the generation of knowledge and innovation. In that same line of thought, Freeman (1991) had specified that business networks have as their main function to gather and process information allowing knowledge creation.

Networks affect innovation hindering or facilitating innovation processes, showing that the number of collaborative relationships is positively related to the production of innovation (Ahuja, 2000). Companies that are linked to one another by collaborative ties have greater opportunity to learn and transfer knowledge. The greater the information flow the better the power to generate innovation (Parachuri, 2009).
Drawing on the fact that innovation can be leveraged through participating into networks, next section discusses this phenomenon which constitutes a crucial factor in ensuring the sustainability of the competitive advantage of firms.

\section{Innovation: Definition and Typology}

Innovation as a major driver of competitive advantage has been well studied in a variety of sectors (Di Serio and Vasconcellos, 2010; Porter, 1983).

An innovation can be understood as the implementation of a new or significantly improved product (good or service), or process, or new marketing method, or new organizational method in business practices, the organization of the workplace or external relations (Organização para a Cooperação e Desenvolvimento Econômico - OCDE, 2005).

Likewise the OCDE (2005), the present study understands that the minimum requirement for an innovation is that the product, process, marketing method or organizational method must be new (or significantly improved) to the firm.

Damanpour (1991) emphasized that to understand the organizational behavior of innovation adoption and its impacts it is necessary to understand innovation typology, and created a classification that divides innovations into three groups, each with a pair of categories.

The first group presents the division between the socalled administrative innovation and technical innovation or technological innovation. The administrative innovation (or organizational innovation) is directly related to the management of the organization and indirectly related to the operating activities, and it is used to characterize innovations in the organizational structure and in the administrative processes. Technical or technological innovation is related to products, services and technology in the production process.

The second group of innovations is related to product innovation and process innovation. A product innovation is related to the creation of new services or new products, and process innovation refers to the introduction of new elements in the operations of production or services - raw materials, task specifications, working mechanisms and information flow and equipment used in the production and delivery of a service.

The third group of innovations distinguishes incremental and radical innovation which refer to the impact caused by the innovations. Radical innovations produce fundamental changes in the activities of an organization, causing a rupture with dominant practices. On the other hand, incremental in-

ISSN: 07 I8-2724. (http://www.jotmi.org)

Journal of Technology Management \& Innovation (c) Universidad Alberto Hurtado, Facultad de Economía y Negocios. 
novations relate to the process of continuous improvement and the pursuit of improving existing products and services (Freeman and Perez, 1988).

In the case of this research, which aims at understanding those innovations developed by SMEs, associated in networks in the supermarket sector, which represent competitive gains to those companies, we must focus on service innovation.

Service innovation differs from the product innovation in three ways according to Berry, et al. (2006): I) the delivery of services is not associated with a tangible product; 2 ) people who perform the services are part of the innovation; and 3) production capacity of companies is decentralized.

As pointed Vargas and Zawislak (2006), three main theoretical approaches have been used in studies of innovation processes that focus on service innovation: a technicist approach, a service-based approach and an integrative approach.

Sundbo and Gallouj (1998) explained the three approaches mentioned above as follows: I) the technicist approach - is based upon the understanding that innovation in services is a result of the adoption of technological innovations developed in the sector of production of capital goods and thus understands that the analysis of service innovation would not be the analysis of a process of innovation itself; 2) the approach based upon services - pays attention to specific forms of innovation in the service sector, as the so called ad hoc innovations, aimed at solving a a client's problem; and 3) the integrative approach - proposes to reconcile goods and services, integrating them into a single theory of innovation. Even highlighting the services' specificities, the integrative approach considers that innovation involves generic features.

Since the interpretation adopted by the technicist approach reduces the notion of innovation to the emergence of a new technical object, disregarding the peculiarities of services (Vargas and Zawislak, 2006), it does not allow a proper analysis of the processes of change inherent to the sector approached by this study. Therefore, we will adopt the integrated approach, of which the analysis of service innovation must assume a rather broad concept of innovation, such as the Schumpeterian conceptualization.

Schumpeter (19II) proposed a broad understanding of innovation, in which innovation can be seen as one of the five following definitions or as a combination of two or more of these definitions: I) the introduction of a new service or a quality change in an existing service; 2 ) the introduction of a new method for delivering a service; 3 ) the opening a new market; 4) the development of a new source of raw materials or other inputs; and 5) the development of a new form of organization in a given industrial sector.

In general, service innovations can be seen as adjustments made in processes. In general this type of innovation presents characteristics of incremental innovations and very few radical innovations (Klement and Yu, 2008).

Sundbo and Gallouj (1998) proposed five types of service innovations:

I. Product Innovation - is related to the provision of a new service;

2. Process innovation - changes in procedures to produce, meet a customer need or deliver a service;

3. Organizational innovation - the introduction of a new management tool or model;

4. Market innovation - is the discovery of a new market, new market niche or new organizational behavior in the company's market;

5.Ad hoc innovation - an innovation that results from a process of problem solving through the co-production of the service, or a solution (strategic, organizational, social, legal) for a particular customer problem.

Given that innovation in SMEs associated in networks from the supermarket sector may involve significant organizational changes, "organizational innovation" needs to be better exploited.

According to the OCDE (2005), organizational innovations aim at increasing a firm's performance by reducing administrative costs or transaction costs, improving workplace satisfaction and productivity, gaining access to non-tradable assets, such as non-codified external knowledge, or reducing costs of supplies.

Wong and Chin (2007) adopted in their work the following definition for organizational innovation: the development or adoption of an idea or behavior in business operations that is new to the whole organization.

Armbrustera, et al. (2008) argue that the main research streams that seek to better understand the phenomenon of organizational innovation see this type of innovation as a necessary adaptation to the introduction of new technologies or as a precondition for the success of a particular product, service or process innovation.

According to the OCDE (2005), one of the aspects that distinguishes organizational innovation from other organizational changes is the implementation of an organizational method that has not been previously used and which is the 
result of strategic decisions made by managers (in business practices, workplace organization, or external relations) as the following:

I. Organizational innovations in business practices may be the implementation of new methods of organizing work routines, such as new practices to improve the knowledge within the company - for example, the first implementation of practices for the development of employees through trainings or the first implementation of management systems for the general production or for the supply operations through systems of supply chain management, business reengineering and quality management;

2. Innovations in the organization of the workplace involve the implementation of new methods for distributing responsibilities and decision-making power - for example, the first implementation of an organizational model that encourages employees to contribute with their ideas;

3. Organizational innovations in external relations involve the implementation of new ways of organizing relations with other firms - for example, the establishment of new methods of integration with suppliers.

The next section will present the methods and procedures used to develop this study.

\section{Method}

This is a qualitative study with a multiple case study design. According to Yin (2009), multiple case studies provide a wider range of results and not limited to the information of a single organization.

The multiple case study involved two networks, one horizontal network and one vertical network, formed by small and medium enterprises. At a first moment we defined those elements which were considered competitive benefits by the companies with their participation in the networks. Secondly, we analyzed those innovation processes that the companies employed to enjoy the competitive benefits.

We judged as being competitive benefits those factors that companies cited as leveraging their competitiveness with their participation in the networks. And innovation, in the present study, is understood as something new for the organizations approached in this study.

Research data was collected from primary and secondary sources. Secondary data came from literature sources and documents and primary data was collected through semistructured interviews with participating companies from two supermarket networks operating in the southern re- gion of Minas Gerais. A vertical network, coordinated by the wholesaler and a horizontal network, coordinated by the participants themselves. These networks were selected to be part of the study due to their relevance in the southern region of Minas Gerais and within networks and business associations in the supermarket sector in Brazil.

16 in-depth interviews were carried out (8 interviews with managers from each of the networks). The interviewees were randomly chosen. These interviews were recorded and later transcribed.After transcribing the recorded interviews, data was analyzed with support of the Sphinx léxica 5.0 software, which is a good software for qualitative data analysis.

From the analysis it was possible to observe the main competitive benefits observed by firms. And from the most cited competitive benefits we developed a theoretical study to classify which were the types of innovations that SMEs developed to reach the competitive benefits.

\section{Results}

Since the respondents' point of view about the major benefits offered by competitive networks differed in the two networks studied, at first we will approach the vertical network and, secondly, the case of horizontal network will be analyzed.

\section{The Vertical Network}

The vertical network approached in this study is coordinated by a wholesaler. In the southern region of Minas Gerais, that network is present in 44 stores in a total of 36 cities. For this research, eight supermarkets' managers from this network, chosen randomly, were interviewed.

According to data analysis, the managers of the supermarkets that are part of this network perceived as the main competitive factors, or competitive benefits, gained from their participation in the network, the following: the Trade Agreement Management, trainings, promotional newspapers, network brand, major events, the loyalty card, purchasing power, legitimacy and status and customer satisfaction, as is shown in Chart I.

The Trade Agreement Management was the most cited competitive benefit among interviewed managers in the network. Five managers cited this factor as a competitive benefit. The Trade Agreement Management was created by the network and is a negotiation between the wholesaler, the network manager, and participating supermarkets. Through this agreement the network participants earn bonuses for purchasing volume. For that, the supermarkets have to assume certain obligations. 
They have to buy specified quantities, exposing the products on the shelves as required by the supplier, among other obligations.

The value of these bonuses exposed by respondents reveal a quite profitable partnership, since this value is often able to defray the expenses with promotional newspapers, and administrative fees, also generating funds for cash withdraw.

In this context, to get the benefits, the companies were faced with the need to make changes in their management structure, redesigning purchases and the display of products on the shelves, according to the supplier's requirements. In that sense, from the changes occurred it can be noted that they constitute an organizational innovation in "business practices'(OCDE, 2005), involving the implementation, for the first time in the companies studied, of management systems for supply operations, an innovation in the management structure of the SMEs.

According to the respondents, trade agreements or negotiations were conducted by the wholesaler and he was in charge of transferring those decisions to the supermarkets. Furthermore it is possible to observe that innovation did not occurred as an initiative departing from the SMEs in the network, but it was imposed by the network manager. Thus, this innovation can be called an innovation from the "top down", departing from the network manager towards the SMEs.

Yet it should be noted that the Trade Agreement Management has led to changes in the company's purchases and disposal of products on the shelves. In that manner, services started to be delivered in a new way constituting a services innovation, or 'process innovation' (Sundbo and Gallouj, 1998).

Four other factors - network brand, trainings, promotional newspapers and big events - were cited in the same proportion.

Network brand - products containing the brand of the network - was much cited, but with complaints about the way it was implemented. Often the network manager stipulates amounts that have to be purchased that are not viable for the company. The advantage commercialize its own brand is the fact that there are no other companies selling the same brand. From the moment the customer becomes loyal to the brand he becomes faithful to the supermarket.

Implementation of the network brand in supermarkets was an organizational innovation, "innovation in business practices' (OCDE, 2005) changing the supply operations in order to adjust the company and allow it to sustain the novelty. It was necessary to make some cuts on purchases of other products. And after the implementation of the network brand, there was innovation in the company's services, 'process innovation' (Sundbo and Gallouj, 1998), for the fact that it was a new way to deliver services.

With respect to trainings - courses offered to employees - they are supplied by the wholesaler to the supermarkets. These trainings are intended to develop those responsible for service delivery. It can be argued that the trainings, promoted a service innovation, or 'process innovation' (Sundbo and Gallouj, 1998), i.e., a new way of delivering the service.

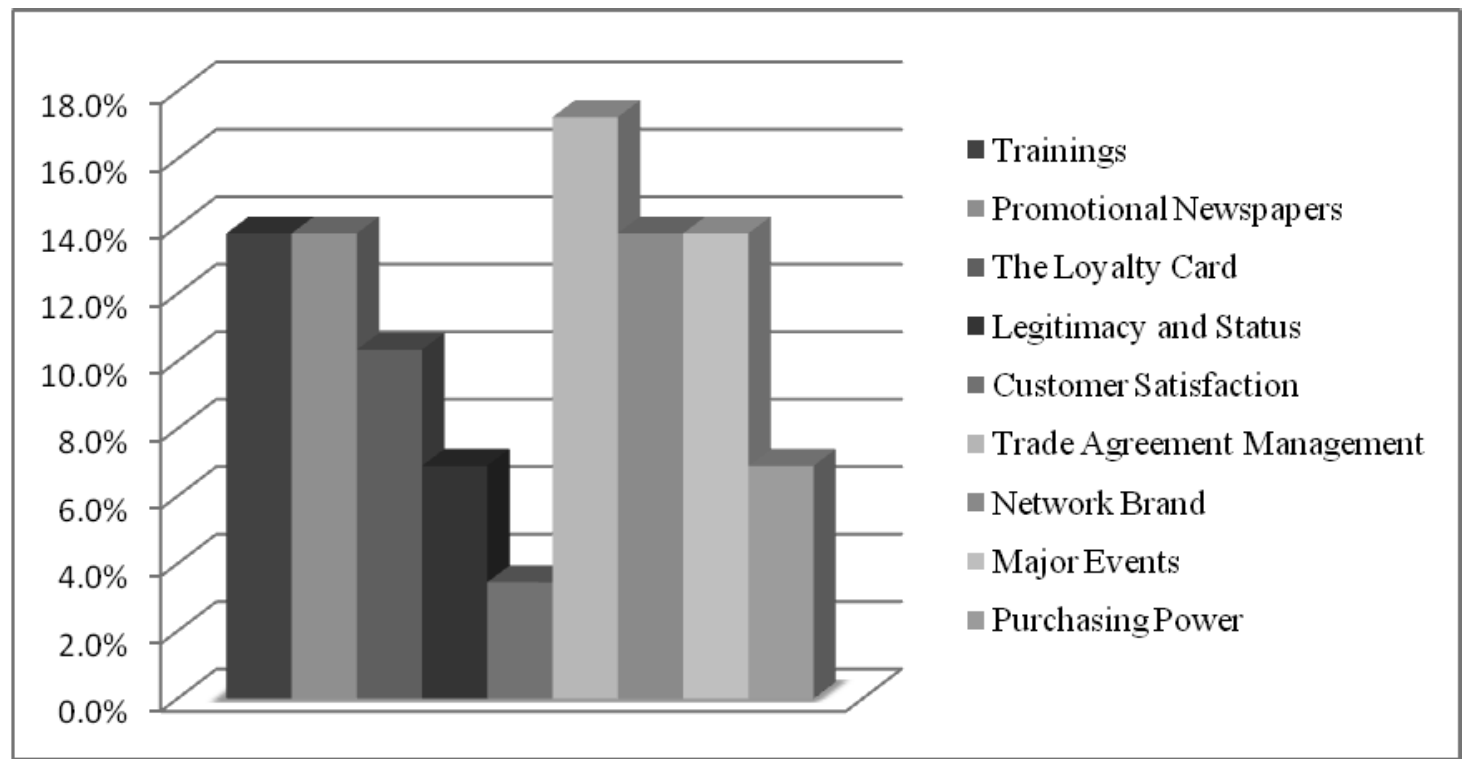

Figure I. Competitive benefits perceived by vertical network managers. Source: Developed form research data

ISSN: 07 I 8-2724. (http://www.jotmi.org)

Journal of Technology Management \& Innovation (c) Universidad Alberto Hurtado, Facultad de Economía y Negocios. 
Nevertheless, the trainings unleashed an organizational innovation, or innovation in the 'business practices' (OCDE, 2005). It was the first implementation of new practices for the development of employees.

The promotional newspaper - newspaper displaying products on sale - was another competitive benefit observed. The promotional newspaper implicitly includes other competitive factors such as promotions, purchasing scale, store advertising, among others. For the newspaper to be implemented the company had to innovate its management process for the fact that in the case of vertical network, there are previously specified amounts that have to be purchased, and despite the meetings to decide on which products to purchase, such a decision was imposed upon companies.

To be able to implement the promotional newspaper, the company had to develop an organizational study to analyze if would have financial resources to sustain it. According to the above, effort to change the management process and support the creation of the newspaper, can also be classified as an organizational innovation, innovation in 'business practices' (OCDE, 2005). Furthermore, given the fact that promotional newspaper is a new service that had not been offered before, it can be considered an innovation in services, 'product innovation' (Sundbo and Gallouj, 1998). The newspaper also represents a new way to deliver the service, which may then be still classified as a 'process innovation' (Sundbo and Gallouj, 1998), innovation in services.

Big events - events provided by the network, such as the car and trip raffles - account for competitive benefits for attract- ing new customers and increasing sales volume. Having in mind the companies only participated in a promotion offered by the wholesale network manager, it is not possible to talk about innovation.

With respect to the main types of innovation occurred in SMEs participating in the vertical network, data analysis showed that the studied companies have implemented different types of innovations in services, according to the understanding and Sundbo and Gallouj (1998). The companies had to innovate organizationally in services in order to be able to implement those competitive benefits. These organizational innovations changed 'business practices' for implementing in the companies for the first time, changes in the management system of operations and supply with respect to the type and quantity of products to be purchased by the companies and the disposal of these products in stores. In addition, it was revealing that some competitive benefits generated other innovations in companies' services: organizational innovation - implementing changes in management practices and 'in the development of employees' - and service innovation - presenting new 'products' and 'processes' to customers, as shown in Table I.

SMEs participating in the vertical network did not perform innovations voluntarily. It was observed that the process of innovation was not an idea of the company, but rather, it was determined by the network manager. Thus, it is possible to classify innovation occurred as an innovation which happens from the "top down", initiated by the manager and imposed on participants. However, the processes of innovation generated competitive benefits to companies participating in the network.

\begin{tabular}{|l|l|l|}
\hline $\begin{array}{l}\text { Innovation before implementing } \\
\text { competitive benefits }\end{array}$ & Competitive Factors & $\begin{array}{l}\text { Innovation after implementing } \\
\text { competitive benefits }\end{array}$ \\
\hline $\begin{array}{l}\text { Organizational Innovation } \\
\text { (changes in business practices, pur- } \\
\text { chases, the array of products on the } \\
\text { shelves) }\end{array}$ & $\begin{array}{l}\text { Trade Agreement Man- } \\
\text { agement }\end{array}$ & Process Innovation \\
\hline $\begin{array}{l}\text { Organizational Innovation } \\
\text { (changes in business practices, the } \\
\text { quantity of products purchased) }\end{array}$ & Network Brand & Process Innovation \\
\hline $\mathrm{X}$ & Trainings & $\begin{array}{l}\text { Process Innovation } \\
\text { Organizational Innovation } \\
\text { (changes in business practices, } \\
\text { practices for the development of } \\
\text { employees) }\end{array}$ \\
\hline $\begin{array}{l}\text { Organizational Innovation } \\
\text { (changes in business practices, pur- } \\
\text { chases) }\end{array}$ & Promotional newspapers & $\begin{array}{l}\text { Product Innovation } \\
\text { Process Innovation }\end{array}$ \\
\hline
\end{tabular}

Table I: Innovations that occurred before and after the implementation of some competitive benefits. Source: Developed from research data

ISSN: 07 I8-2724. (http://www.jotmi.org) 


\section{The Horizontal Network}

The horizontal network includes 13 member companies in 16 cities in the southern region of Minas Gerais and 3 cities in the state of São Paulo. In a total of 21 stores, 4 stores are owned by the network. We have interviewed managers of 8 participating supermarkets.

According to the analysis of the research data, the managers of supermarkets in this network understand the following aspects as major competitive factors, or competitive benefits, acquired from their association into networks: promotional newspapers, trainings, status and legitimacy, customer satisfaction, network brand, purchasing power, logistics and Trade Agreement Management, as shown in Figure 2.

The network brand is the competitive benefit most cited among respondents. It can be observed that factor is more relevant for horizontal network participants if compared to the perception of vertical network participants. Problems previously cited as how to implement changes and innovation do not occur in this network since decisions are made jointly. Therefore, one can see that the innovation process is done voluntarily, in search of competitive advantages.

For the network brand to be implemented in this network it was also necessary that companies innovated organizationally. Organizational innovation 'in the business practices' (OCDE, 2005) took place as companies needed to make changes in the quantities and types of products purchased. Subsequently, we verified the occurrence of innovation in services, or 'innovation process' (Sundbo and Gallouj, 1998) due to the change in the way of delivering customer service. Promotional newspapers were also more cited in this network than in the vertical network. This fact may be explained due to the decisions taken by the majority of the group, generating a lower propensity to dissent. As for innovation processes, this factor, as well as the network brand, also implied the need of implementing organizational innovation 'in business practices' (OCDE, 2005). The company had to innovate its management process. Implementing the promotional newspaper, the company had to make changes regarding the amount of products purchased.After its implementation, the promotional newspaper generated service innovations, or 'product' innovations (Sundbo and Gallouj, 1998), as a new service started being offered to consumers. The promotional newspaper implementation generated a 'process' innovation as well (Sundbo and Gallouj, 1998), considering that the service also had to be delivered in a new way.

Trainings and Trade Agreement Management were also cited as competitive benefits, as in the first network analyzed, but in different proportions. Considering innovation types, it is possible to observe that training has generated innovation in services, or 'process' innovation, and organizational innovation 'in business practices' for the fact that it was the first time that new practices of employee development were implemented.

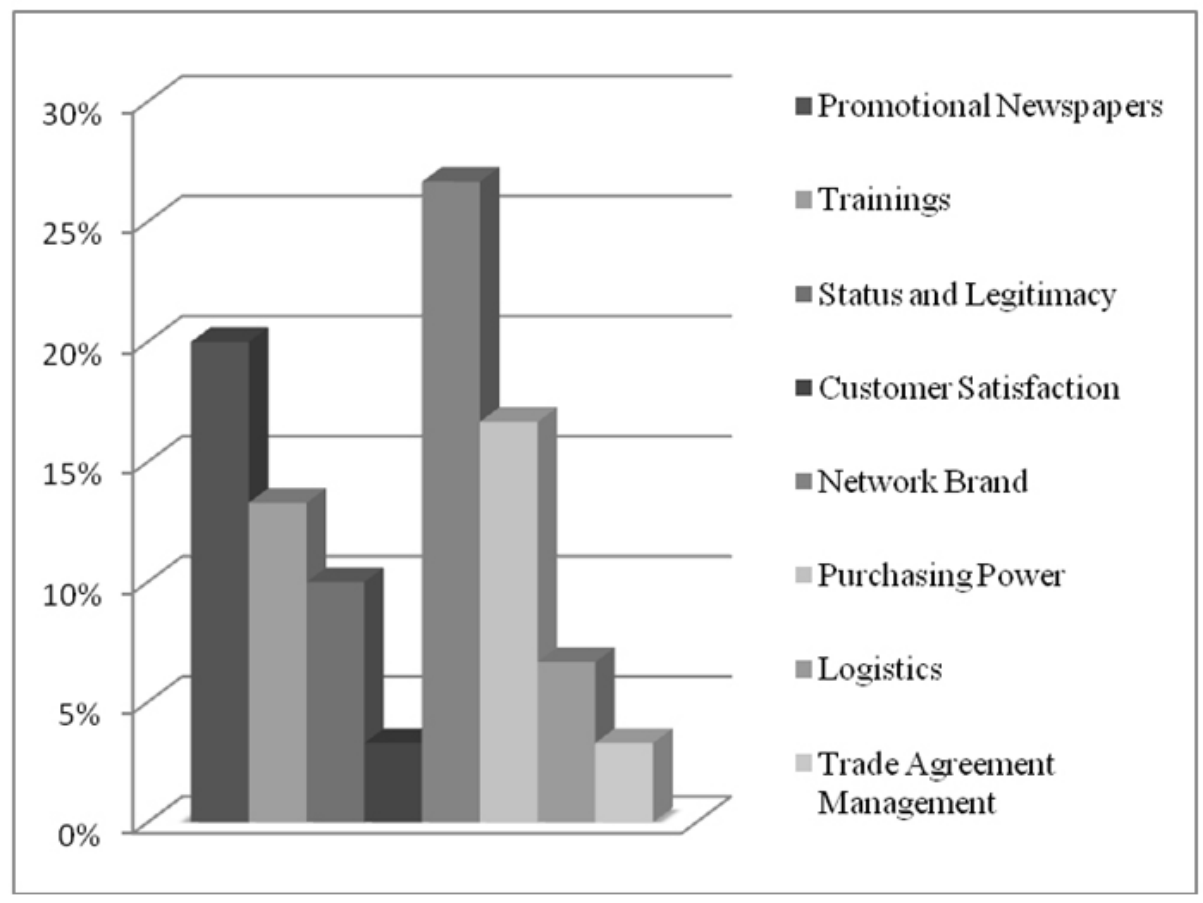

Figure 2. Competitive Benefits perceived by horizontal network managers. Source: Developed form research data

ISSN: 07I 8-2724. (http://www.jotmi.org)

Journal of Technology Management \& Innovation (c) Universidad Alberto Hurtado, Facultad de Economía y Negocios. 
To be able to establish Trade Agreement Management companies found the need to innovate organizationally 'in business practices' as they had to change how to negotiate, due to limits on quantities of products purchased from certain suppliers. After establishing the Trade Agreement Management, innovation in services, or 'process' innovation, could be observed as the service had to be delivered in a new way.

Logistics - transporting products and their availability in time and place determined by the network distribution center - was also a competitive benefit cited in this network. To benefit from integrated logistics supermarkets had to innovate organizationally. Suppliers started delivering to the distribution center, and from there, the goods were delivered to companies participating in the network.

In this context companies innovated organizationally in business practices' due to the introduction of changes in the system of supply chain management (OCDE, 2005), which have an impact on the supply operations of these companies.

Considering the main types of innovation occurred in SMEs participating in the horizontal network, it can be seen that there were different service innovations. Organizational innovation changed 'business practices' of companies, supply operations and management systems of suppliers so that the competitive benefits were implemented. We could also see service innovation, or 'organizational' innovation, changing 'business management practices', training employees. And service innovations 'of product' and 'process', which introduced a new service to customers and a new way to deliver those services, as shown in Table 2.

This network differs from the vertical network in the frequency with which respondents cite competitive factors. In addition, in the horizontal network logistics is considered a competitive factor, as is shown in Graph 2.

Another perceived difference comparing this network to the vertical network is that innovation processes of the participating supermarkets in the horizontal network are established by the managers in search of competitive advantages. This can be classified as an innovation from the "bottom-up". In this type of innovation, the decision is made by the managers of SMEs and then becomes a process in the network. Discussion

For SMEs to join a network, it is usually a requirement that they implement a restructuring process in order to acquire the culture of the group, beginning to act differently. This type of innovation was not the focus of this study. Innovations that have been addressed by this research were those implemented by SMEs in their services and in their management practices when they were already part of networks.

\begin{tabular}{|l|l|l|}
\hline $\begin{array}{l}\text { Innovation before implementing } \\
\text { competitive benefits }\end{array}$ & Competitive benefits & $\begin{array}{l}\text { Innovation after implementing } \\
\text { competitive benefits }\end{array}$ \\
\hline $\begin{array}{l}\text { Organizational Innovation } \\
\text { changes in business practices, the } \\
\text { purchases of products) }\end{array}$ & Network Brand & Process Innovation \\
\hline $\begin{array}{l}\text { Organizational Innovation } \\
\text { (changes in business practices, in } \\
\text { purchases) }\end{array}$ & Newspaper Offers & $\begin{array}{l}\text { Product Innovation } \\
\text { Process Innovation }\end{array}$ \\
\hline $\mathbf{X}$ & Training & $\begin{array}{l}\text { Process Innovation } \\
\text { Organizational Innovation } \\
\text { (changes in business practices, } \\
\text { practices for the development of } \\
\text { employees) }\end{array}$ \\
\hline $\begin{array}{l}\text { Organizational Innovation } \\
\text { (changes in business practices, pur- } \\
\text { chasing, the array of products on the } \\
\text { shelves) }\end{array}$ & GAC & Process Innovation \\
\hline $\begin{array}{l}\text { Organizational Innovation } \\
\text { changes in business practices, the } \\
\text { supplier shall deliver the products at } \\
\text { the distribution center) }\end{array}$ & Logistics & X \\
\hline
\end{tabular}

Table 2: Innovations that occurred before and after the implementation of some competitive benefits. Source: Developed from research data

ISSN: 07I 8-2724. (http://www.jotmi.org)

Journal of Technology Management \& Innovation (c) Universidad Alberto Hurtado, Facultad de Economía y Negocios. 
Thus, the present study had as its main objective to analyze some types of innovations that SMEs already associated into vertical or horizontal networks establish in order to access those benefits they consider competitive benefits offered by the network, such as the purchasing power, network brand and promotional newspapers. These were considered innovations before the implementation of the competitive benefits.

In fact, it was possible to observe that innovation is directly linked to competitive benefits gained from participating in networks. If the companies approached in this study were to enjoy the gains in competitiveness provided by the factors they considered competitive, offered by the network, they had to implement changes in their management tools, such as redesigning of inventory, rearranging products on the supermarket shelves, among others.

The implementation of the factors considered competitive, obtained from the participation of SMEs in networks, also spawned other innovations in the companies. For instance, the training provided to employees generated organizational innovation in services by implementing changes in the practices of employee development and also generated process innovation in services. Given that employees have direct contact with customers, changes in the way customers' needs are met, constitutes a change in service, representing process innovation in services when it is the first time that particular change is implemented.

Another innovation occurred in services that could be classified as a process innovation, after the implementation of the benefits considered competitive, originated from changes triggered with the implementation of the network brand that can also be considered as a new way to deliver services to the customer.

With the promotional newspapers, besides service innovation in processes we can also note service innovation in products, since the newspaper started to deliver the service in a new way, but also offered a service that had not been previously offered.

The two networks approached in this study showed some significant differences. For example if one takes into account the frequency with which respondents cite factors such as competitive. Moreover, in the horizontal network, logistics is considered a competitive factor that led companies to innovate organizationally in business practices due to the introduction of changes in the management system of the supply chain, affecting supply operations.

Innovation processes were also different considering their form in the two networks. In the vertical network innova- tion occurs from the 'top-down', it begins with the network manager and is imposed on participants, since the process of innovation is not a decision taken by the managers of SMEs but by the wholesaler network manager. In the case of horizontal network, innovation occurs from the 'bottomup', and decision is made by the managers of SMEs and then becomes a process in network.

All of these findings lead to the conclusion that for SMEs associated into networks to access the main factors considered competitive, they need to innovate organizationally. In addition, some competitive factors offered by the network promoted other organizational service innovations, product innovations and process innovations.

Although the results of this study do not present the possibility of generalization or explanation of other sectors, and emphasizing that further studies need to be developed to better explore the results with respect to service innovation in the supermarket sector, it was confirmed that innovation besides being a decisive factor for the competitiveness of SMEs associated in networks, it is often crucial for companies to offer new services or new value to customers and benefit from new market opportunities. 


\section{References}

AHUJA, G. (2000). Collaboration networks, structural holes, and innovation: a longitudinal study. Adminintrative Science Quarterly, 45 (3), 425-455.

AMATO NETO, J. (2000). Redes de cooperação produtiva e clusters regionais: oportunidades para as pequenas e médias empresas. Atlas, São Paulo.

ARMBRUSTERA, H. Bikfalvib, A. Kinkela, S. Laya, G. (2008). Organizational innovation: the challenge of measuring nontechnical innovation in large-scale surveys. Technovation, 28, 644-657.

BALESTRIN, A. Vargas, LM. (2004). A dimensão estratégica das redes horizontais de PMEs: teorizações e evidências. Revista de Administração Contemporânea, 8, 203-227.

BAUM, JAC. Ingram, P. (2000). Interorganizational learning and network organization: toward a behavioral theory of the interfirm. In: March, JG.Augier, M. (Eds.), A tribute to Richard M. Cyert. Edward Elgar,Aldershot.

BERRY, LL. Shanker, V. Parish, JT. Candwallader, S. Dotzel, T. (2006). Creating new markets through service innovation. MIT Sloan Management Review, 47 (2), 56-63.

BORGATTI, SP. Foster, P. (2003). The network paradigm in organizational research: a review and typology. Journal of Management, 6 (29), 99I-1013.

CASAROTTO FILHO, N. Pires, LH. (1998). Redes de pequenas e médias empresas e desenvolvimento local: estratégias para a conquista da competitividade global com base na experiência italiana. Altas, São Paulo.

CASTELLS, M. (2007). A sociedade em rede: a era da informação: economia, sociedade e cultura. Paz e Terra, São Paulo.

DAMANPOUR, F. (|99|). Organizational innovation: a meta analysis of effects of determinants and moderators.Academy of Management Journal, 34 (3), 355-390.

DI SERIO, LC. Vasconcelos, MA. (2009). Estratégia e competitividade empresarial: inovação e criação de valor. Saraiva, São Paulo.

FREEMAN, C. (199I). Network of innovators: a synthesis of research issues. Research Policy, 20, 499-5I4.

FREEMAN, C. Perez, C. (1988). Structural crises of adjustment. In: Dosi, G. Freeman, C. Nelson, R. Silverberg, G. Soete, L. (Eds.), Technical change and economic theory. Printer, London.
KLEMENT, CFF. Yu, Aso. (2008). Influências da tecnologia para a inovação em serviços. Revista de Administração, I (I), I0I-II5.

NOHRIA, N. (1992). Is a network perspective a useful way of studying organizations? In: Nohria, N. Eccles, RG. (Eds.), Networks and organizations: structure, form, and action. Harvard Business School, Boston.

OLIVARES, JEL. (2003). Análise da estrutura organizacional em rede e suas negociações no contexto das alianças estratégicas. Tese de Doutorado, Universidade de São Paulo, São Paulo.

Organização para a Cooperação e Desenvolvimento Econômico. (2005). Manual de Oslo: diretrizes para coleta e interpretação de dados sobre inovação. OCDE/Eurostat, Paris.

PARACHURI, S. (2009). Intraorganizational networks, interorganizational networks, and the impact of central inventors: a longitudinal study of pharmaceutical firms. Organization Science, 20, I-18.

PORTER, ME. (1983). The technological dimension of competitive strategy. In: Research on technological innovation, management, and policy.JAI, Greenwich.

SCHUMPETER, J. (I9II). Teoria do desenvolvimento econômico.Abril Cultural, São Paulo.

SUNDBO, J. Gallouj, F. (I998). Innovation in service. STEP Group, Oslo.

VARGAS, ER. Zawislak, PA. (2006). Inovaçăo em serviços no paradigma da economia do aprendizado: a pertinęncia de uma dimensăo espacial na abordagem dos sistemas de inovação. Revista de Administração Contemporânea, I0 (I), 139-159.

WONG, S. Chin, K. (2007). Organizational innovation management: an organization-wide perspective. Industrial Management \& Data Systems, I07 (9), | 290-I3I5.

YIN, RK. (2009). Case study research: design and methods. Sage, London.

ISSN: 07 I8-2724. (http://www.jotmi.org) 